\title{
Being there?: A Collaborative Inquiry into Attendance
}

\section{Menendez Alvarez-Hevia, David; Lord, Janet and Naylor, Steven}

Department of Childhood, Youth and Education Studies, UK, Manchester Metropolitan University

\begin{abstract}
There is a growing concern among universities over the levels of student absenteeism at teaching activities. Attendance is an increasingly important issue in the UK, but also internationally, for its impact on the student experience, academic performance and engagement. This article explores the topic of poor attendance in one of the larger universities in the UK, through a collaborative action research methodology that includes Education Studies lecturers and students as research partners. Initial findings suggest that attendance is conceptualised in different ways by different actors. We found that a key theme in understanding attendance and engagement was that students' identities are multi-layered and complex, and that their identities as students are often interwoven. We also found that technology and the virtual world play a fundamental role in understanding practices and conceptualising attendance and engagement. Concerning this, the way that a Virtual Learning Environments is approached in our study illustrates how physical attendance is challenged (but also supported) as a privileged form of getting access to the knowledge presented in taught sessions.
\end{abstract}

Keywords: Attendance, engagement, collaborative research, student experience. 


\section{Introduction}

It is clear from the literature that non-attendance at teaching sessions affects students in different ways (Kelley, 2012; Barlow \& Fletcher 2011; Massingham \& Herrington, 2006) and is a matter of considerable importance for lecturers and higher education institutions (Morgan, 2001; Moore, Armstrong \& Pearson, 2008; Bowen et al., 2005). Although attendance is generally studied in relation to performance achievement (Arulampalam, Naylor \& Smith, 2012; Chamberlain, 2012; Allen \& Webber, 2010), this study aims to take a more critical approach, examining practices to improve attendance, their implications and possibilities and illuminating different ways of conceptualising the "problem of attendance" at lectures, seminars and other academic activities. Whilst there is a tendency to represent students as consumers (economic subjects), rather than being reflective or productive (economic character) or individualistic (economic citizenship) (Brown, 2015; Molesworth, Scullion and Nixon, 2011), through this project on attendance, we also take a political standpoint by committing ourselves to uncover narratives that contribute to challenge that form of representation and contribute generating new ideas and positions.

The notion of attendance for us, also alludes to larger contemporary debates around physical and non-physical presence. It has been recognised that many people, both young and old, are often spending a lot of time managing multiple presences through online or virtual identities and this creates an strange sense in which being together with other people is not as straightforward as bein in their physical presence (see Turkle, 2012). This research aims to go beyond a debate that is seen, for example, in terms of student disaffection with lecture content. We interrogate the notions of being present and challenge the idea that attendance is just about 'being there', in order to develop a more nuanced understanding of what this means for learning in higher education.

Attendance has emerged as a "problem" for some programmes at our institution (a university in the North West of the UK) with a preliminary investigation showing that attendance rates at teaching sessions (lectures, seminars and tutorials) have dropped dramatically over recent academic years. Institutional responses involving different strategies were put in place, but without consultation or consideration of the view of the relevant actors and without a clear plan for evaluation. Some of these strategies include new electronic systems to monitor attendance, introduction of pedagogical innovations such as small group teaching or more blended learning, a new logic in the way of organising taught sessions that include a combination of "short and fat" modules with "large and thin" modules and presenting learning material via a virtual learning environment. Langan and Whitton (2016) have recently studied learners' disengagement within the context of this institution in the areas of psychology and business, but not in education. Their findings, which are aligned with previous literature, recognise some core areas of the student 
experience that are associated with non- attendance and suggest that explanations should be negotiated at local levels.

We planned this research project inspired by the idea that developing a local understanding of the topic would allow us (as Education Studies students and lecturers) to include multiple voices on the implementation and evaluation of initiatives that aim to improve attendance.

From previous discussion and the exploration of the literature three main question emerged to focus the study:

1. How is attendance conceptualised by students and lecturers?

2. Do current strategies, at pedagogical, organisational and institutional levels have an impact on attendance?

3. How might the notion of 'being there' for students be made relevant?

\section{Methodology}

This research takes a Collaborative Action Research (CAR) approach that involves conducting research from inside and with others, focusing on improving practices and generating knowledge through reflection, collaboration and transformation (McNiff, 2016). This form of research 'integrates the development of practice with the construction of research knowledge in a cyclical process' (Noffke \& Somekh, 2005: 89). There is a significant tradition of CAR research in the area of education that supports its implementation and promotion for a study of this kind (e.g.Kember, 2000; Hollingsworth, 2001; Baumfield, Hall \& Wall, 2008). An examples of the use of AR on the topic of attendance is presented by Gbadamosi (2015) who uses this approach to understand why students were not attending seminars, at the same time as he implements new teaching practices to improve attendance.

Our CAR project included 3 lecturers and 12 students that participate as co-researchers, to embed a student-lecturer perspective throughout the study. They are distributed in three research teams of 1 lecturer and 4 students. Each research group is in charge of one specific elements related to the topic of attendance (individual or personal aspects, pedagogical aspects and organisational or institutional aspects). Three main meetings were used to discuss (and generate) data, emerging issues and further steps. More details about the structure of this research can be found in figure 1 : 


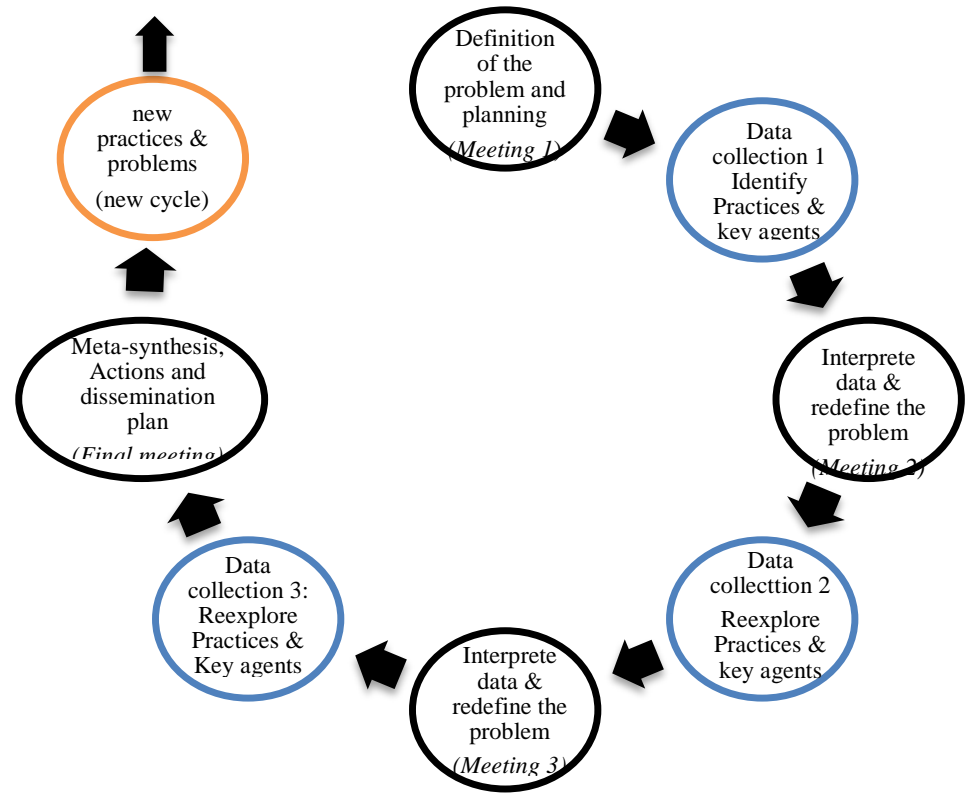

Figure 1. Action Research cycle dapted from the classic action-reflection cycle developed by Lewin (1946)

In addition to attending the 4 main meetings, the groups meet regularly to carry out research activities. These groups work independently, collecting and reflecting on different forms of data that include: data from interviews with different agents (students, academic and non-academic staff and representatives from the student union or student services), secondary data (university policies and data from the Student Engagement office), notes from meetings, and reflective activities in the form of reflective diaries, logs and/or personal journals. A final all-day meeting is dedicated to meta-synthesis (analysis of data across groups), discussion of findings and the production of dissemination material. Diverse techniques and strategies to analyse data were employed (e.g. descriptive statistics, thematic analysis, discourse analysis).

Underpinning this study is the presupposition that equality is not a goal, but a point of departure. We are inspired by Rancière's understanding (1991) of the equality of intelligences that makes us conscious of the necessity of believing in the possibilities of what can be done with equality. This involves a continuous interrogation and verification of the principle of equality as part of the research process. In other words, students as researchers are considered as fully capable beings that have the possibility to act and respond, bringing into the world original and valuable ideas, points of views and make tensions manifest. 


\section{Preliminary findings and discussion}

Although this study is still in progress, we can advance some relevant findings. Some of the changes evaluated by the research teams include the introduction of new electronic monitoring system in which students register their attendance to lecture and seminars using a card-reader system. Changes to the timetable, teaching methods, distribution of assessment dates and forms of taught session, are also all discussed within the research teams.

Our findings suggest that attendance is conceptualised in different ways by lecturers, students and other agents (e.g. senior managers and student engagement officers). All of them understand that the level of attendance have some implications for academic performance. However, there is evidence that shows disagreement in the way that they perceive attendance as a "problem" and the implementation of new initiatives at university level to improve attendance. For example, there are some tensions in the way that the new electronic monitoring systems are introduced. This system is praised by senior managers and students engagement officers whereas for some students it is a form of "depersonalization". Although students recognize the benefits of an electronic system, they also see what is missed with electronic initiatives to record attendance:

I think the lecturers should interact with the students so they know who is in...so they can actually draw into them and maybe it's more time consuming...(Year 1 student, Focus group 1, Group D).

Lecturers can see some of the adventages of the electronic system, but for some of them it comes with implications for their identity as educators:

There are ways of checking, I'm looking for patterns of all of the people who come in late because this new tech allows us to do this. On the other hand, I don't want to be doing this...I'm not the police, so I understand that the people are coming in late (Lecturer, Focus group 2, Group D).

For others there is an ambivalance,

I don't care what the university does in terms of swiping or the other methods. I will always, always, always, always take a paper register, so that if something goes wrong electronically I'm very aware of whether students have been in or not...it seems quite old fashioned to have a paper register but I like the security of it. (Lecturer S, interview, Group J)

Staff also feel the lack of consultation over the system keenly, as this means (for example) that when registering students their previous attendance record, and hence patterns, are not readily available. 
Students value the efforts made by lecturers and the institutions to improve their student experience although they think it is still insufficient. They see on the type/structure of the teaching session a powerful motivator to attend/miss lectures:

Erm... for enrichment I make sure I attend because it's all activity based but like the other ones you know when they are just talking and your like ahhh...you are like I can just see it on Moodle...(Student, Focus group 2, Group S)

They agree with lectures that absenteeism to lectures and seminar have a negative impact on their learning experience. Neither students and lecturers like the experience of "an empty room", specially if it is a lecture theatre. For lecturers it has implications for the way that they plan activities. For one lecturer, the planning was all around the social nature of learning, and hence attendance was key;

... I won't read out what's on the slides it's all ... really about talking about the particular issues and making those connections and trying to keep it kind of lively and going in that way. (Lecturer E, interview, group J)

Students also consider that physical attendance is not always essential, as materials are available via the virtual learning environment (VLE); they suggested that often they learn better by studying lecture notes when they are on their own, and that in fact good quality materials on the VLE can discourage physical attendance;

If you go to a session but the tutor will [upload] good quality material and you didn't have to make that 2 hour drive and you could just look at the material on Moodle. (Student, focus group 2, group J).

However, they did value the collaborative learning experiences planned by staff.

We found that a key theme in understanding attendance and engagement was that students' identities are multi-layered and complex, and that their identities as students are often interwoven with those of (say) parent, and/or employee. There are tensions involved in the lived realities of students' lives, for example in paying substantial fees as well as completing assignments; those tensions are reflected in the multiple identities that students experience and exhibit. For example, in order to pay fees and for accommodation, students often need to work, and their employment contracts may limit their ability to attend lectures. In addition, the interaction between the multiplicity and variety of factors that impact on physical attendance (such as session timing, closeness to assignment submission dates, childcare and travel arrangements and the use of technology in learning) plays a fundamental role in the understanding of practices and the ways that attendance and engagement are conceptualised. 


\section{Conclusion}

This CAR project contributes to enhance the student experience, improve the research capability of lecturers and provide guidance for the University. The research design required participants to operate at personal, professional and political levels (Noffke 2009), providing opportunities to reshape their world and identity. The project presents opportunities for students to participate as researchers and contributes to reshaping the ways that Education Studies students, lecturers and other university agents understand the topic of attendance. Therefore, the project has a direct impact on the students who participate but also influence teaching practices and inform university policies more broadly. On a theoretical level, the project provides comprehensive insight into the ways that attendance is problematized and conceptualised from different perspectives. At policy level, this study offers recommendations to key agents by examining current attendance policies from different perspectives and proposing alternatives. Finally, this project also provides support for teaching practices by providing guidance for lecturers (e.g. the coconstructed dissemination materials are shared as part of departmental professional development days, seminars and short reports) and as materials that could be used to discuss attendance with students. The evaluation of strategies at a local level are used to inform key agents about their current strategies and alternatives.

\section{References}

Allen, D. \& Webber, D.J. (2010). Attendance and exam performance at university: a case study. Journal of Research in Post-Compulsory Education, 15 (1), 33-47.

Arulampalam, W., Naylor, R. and Smith, J. (2012). Am I Missing Something? The Effects of Absence from Class on Student Performance. Economics of Education, 31 (4), 363375

Barlow, J and Fletcher, S. (2011). Student absenteeism: whose responsibility?. Innovations in Education \& Teaching International, 48 (3), 227-237.

Baumfield, V., Hall, E. and Wall, K. (2008). Action research in the classroom. London: SAGE.

Bowen, E. Price,T. Lloyd, S. and Thomas, S. (2005). Improving the quantity and quality of attendance data to enhance student retention. Journal of Further and Higher Education, 29 (4), 375-385.

Brown, W. (2015). Undoing the Demos: Neoliberalism's stealth revolution. New York: Zone books.

Burke, P. (2002). Towards a collaborative methodology: an ethnography of widening educational participation. The Australian Educational Researcher, 29(1), 115-136.

Chamberlain, J. M. (2012). Grades and Attendance: Is There a Link between Them with Respect to First Year Undergraduate Criminology Students? Educational Research and Reviews, 7 (1), 5-9. 
Gbadamosi, G. (2015). Should we bother improving students' attendance at seminars? Innovations in Education \& Teaching International, 52 (2), 196-206.

Hollingsworth, S. (ed) (2001). International Action Research: a casebook for educational reform. Washington: Falmer Press.

Kelly, G. (2012). Lecture attendance rates at university and related factors. Journal of Further and Higher Education, 36 (1), 17-40.

Kember, D. (2000). Action learning and action research: improving the quality of teaching and learning. London: Kogan Page.

Langan, M. and Witton, N. (2016). Understanding Learner Disengagement: Why do students pay $£ 9,000$ a year not to attend lectures? Learning and Teaching in Action, 12(1), 56-70.

Lewin, K. (1946). Action research and minority problems. Journal of social issues, 2 (4), $34-46$.

Locke, T., Alcorn, N. and O'Neill, J. (2013). Ethical issues in collaborative action research. Educational Action Research, 21 (1), 107-123.

Mason, J. (2002). The discipline of noticing. Oxon: Routledge.

Massingham, P.and Herrington, T. (2006). Does attendance matter? An examination of student attitudes, participation, performance and attendance. Journal of University Teaching and Learning Practice, 3 (2), 82-103.

McNiff, J. (2016). You and your action research project. London: Routledge.

Molesworth, M., Scullion, R. and Nixon, E. (eds) (2011). The Marketisation of Higher Education and the Student as Consumer. London: Routledge.

Moore, S., Armstrong, C., Pearson, J., (2008). Lecture absenteeism among students in higher education: a valuable route to understanding student motivation. Journal of Higher Education Policy and Management, 30 (1), 15-24.

Nofffke, S. (2009). 'Revisiting the professional, personal and political dimensions of action research', in S.Noffke and B. Somekh (eds) The Sage Handbook of Educational Action Research. (pp. 6-23) London: Sage.

Rancière, J. (1991). The ignorant schoolmaster: five lessons in intellectual emancipation. Stanford: Stanford university press.

Somekh, B. and Lewin, C. (2003). 'Action Research', in B.Someck and Lewin, C. (eds) Research Methods in the social sciences (pp. 89-96). London: Sage.

Turkle, S (2011). Alone Together: Why we expect more from technology and less from each other., New York: Basic Books.

Zeni, J. (2009). 'Ethics and the personal in Action Research', in S.Noffke and B. Somekh (eds) The Sage Handbook of Educational Action Research (pp. 254-267). London: Sage. 